\title{
Francisco Suárez and the Complexities of Modernity
}

\author{
Juan Antonio Senent-De Frutos ${ }^{1}$ \\ Universidad Loyola Andalucía \\ jasenent@uloyola.es
}

\begin{abstract}
I present here a key to reading the work of Jesuit thinker Francisco Suárez in the context of the plurality and complexity of modernity. I show the main configuration that defines modernity in its hegemonic version, as well as its limitations. From there, I propose how Suárez's work can be understood from the perspective of its own Ignatian and Jesuit spiritual framework and in relation to the development of modernity. Although a dominant version of modernity has historically prevailed, modernity cannot be understood as a uniform process but one that has been articulated and expressed in different civilizing missions since the Renaissance. One modern way of responding to the socio-cultural challenges of the Renaissance was articulated by the Society of Jesus. I believe that in light of what I term an "Ignatian modernity," we can better understand Suárez's intellectual mission, its historical virtuality, and the possibilities marginalized by hegemonic modernity.
\end{abstract}

\section{Keywords}

Francisco Suárez - modernity - ignatian modernity - early modernity - Suarezian political modernity

\section{$1 \quad$ Jesuits since Modernity}

This article about Francisco Suárez in the context of modernity ${ }^{2}$ is set in a broader context of research we are developing on the "Ignatian cultural

1 Professor of legal philosophy and political philosophy and director of the Department of Humanities and Philosophy at the Universidad Loyola Andalucía.

2 This article develops the presentation made as the co-organizer of the International Symposium on Jesuit Studies (Department of Humanities and Philosophy, Universidad Loyola

(C) JUAN ANTONIO SENENT-DE FRUTOS, 2019 | DOI:10.1163/22141332-00604001

This is an open access article distributed under the terms of the prevailing CC-BY-NC license at the time of publication. 
framework" in general and specifically on Suárez's work. ${ }^{3}$ In this context, the article analyzes Francisco Suárez's thinking in two contexts, both with respect to his own era and subsequent influence as well as to our own era, and it links to a hermeneutic and practical will that can be discerned in the symposium title Francisco Suárez (1548-1617): Jesuits and the Complexities of Modernity, as I clarify in this article. This author is recognized as a theologian, philosopher, and jurist who had a significant cultural impact on the beginning and development of modernity. Around the fourth centenary of his death, ${ }^{4}$ we have studied the work of Suárez and other Jesuits of his time in the context of the various traditions that converged in Europe during the late medieval, Renaissance, and early modern periods. ${ }^{5}$ In doing so, we were guided by some questions that framed the dialogue with this Jesuit thinker and his colleagues in the Society of Jesus.

The first question is: Can the work of the Jesuits be seen both as a precursor to philosophical, political, or legal modernity and as an expression of an alternative modernity? Second, what is the relationship between the Ignatian and Jesuit traditions and the development of the work of Suárez and his contemporaries? Third, what elements of the work of Suárez and other Jesuits are relevant to confronting the crisis of modernity today?

Andalucía and Institute for Advanced Jesuit Studies, Boston College), held in Seville June 1-2, 2018.

3 This study is currently being carried out as part of the Research Project "Jesuit thought and tradition: its influence on modernity from the perspective of history, translation studies, and legal, moral and political (PEMOSJ), reference FFI2015-64451-R. The project is funded by the Ministry of Economy and Competitiveness of the Spanish Government and the European Regional Development Fund (MIneco/Feder). Lead Researcher: Juan Antonio Senent-De Frutos.

4 A list of academic events on the legacy of Francisco Suárez held around the world on the occasion of the quadricentenary of his death can be found in Manuel Lázaro Pulido and María Idoya Zorroza Huarte, "Memoria peninsular de un legado para el siglo XXI: Francisco Suárez (1617-2017)," Pensamiento: Revista de investigación e información filosófica 279 (2018): 299-318, doi: 10.14422/pen.v74.i279 and 2018.015.

5 However, I do not share the theoretical strategy developed by Benjamin Hill that considers him as a hybrid thinker without a character of his own, "a transitional figure, partly medieval and partly modern, who occupied a middle ground in the continuous sweep of history from the medieval thought, the Renaissance and early modern periods." See "Introduction," in The Philosophy of Francisco Suárez, Benjamin Hill and Henrik Lagerlund, eds. (Oxford: Oxford University Press, 2012), 1-21, here 5. One must not confuse a proper understanding of Suárez's intellectual mission with a description of the various intellectual currents of his day-with which Suárez dialogued and by which he was influenced — nor with the difficulty of applying to Suárez the usual taxonomic categories of the history of philosophy. Noting that Suárez is partly involved in various currents is not a direct answer but merely circumstantial and external to the meaning of his work. 
These questions open areas of discussion that are addressed from the perspective of various disciplines and topics, ranging from metaphysics, epistemology, anthropology, psychology, philosophy of religion, the dialogue among religions, and theology to practical legal, moral, political, and social philosophy, and extending to philology and history. ${ }^{6}$ These inquiries and reflections serve to advance the task of recovering the legacy of Suárez, to which several researchers have given new impetus in recent years. ${ }^{7}$

For our part, we also intend to focus on this recovery and redefinition of the legacy of Suárez and the early Jesuits in an attempt to rethink what is distinct and different about Jesuit thinking and its process of building relationships in the world with regard to the complex, ambivalent, and heterogeneous way modernity plays out in its historical development. We ask how this difference might prove relevant, in terms of culture and civilization, to facing the current challenges of our globalized world and to the cultural context of the crisis of modernity. In this regard, I see "Jesuit and Ignatian studies" not simply as a field of research or a historical object but as offering an opportunity and a practical inspiration to continue recreating ways of life with humanistic qualities.

This process entails going back to contrast and rethink the assumptions underlying common interpretations of the way Jesuits treated the diversity of societies, cultures, and religions. The Black Legend 8 that surrounds the Society of Jesus makes it difficult to see its contribution and potential to rebuild relations in our world together with other traditions and ways of life. On the other hand, I do not intend to deliver a sermon portraying Jesuits as saints, nor to justify every mission or proposal that emerged from the ranks of Jesuit thinkers merely because they were associated with that institution. This article is not about restoring but about better understanding and even seeing the benefit that can be gleaned from these concepts, considering the ethical and spiritual core of

6 These contributions have been published in a volume edited by Robert A. Maryks and Juan Antonio Senent-De Frutos, Francisco Suárez (1548-1617): Jesuits and the Complexities of Modernity (Leiden: Brill, 2019).

7 These include José Pereira, Between Scholasticism and Modernity (Milwaukee: Marquette University Press, 2006); Marco Sgarbi, Francisco Suárez and His Legacy: The Impact of Suarezian Metaphysics and Epistemology on Modern Philosophy (Milan: Vita e Pensiero, 2010); John P. Doyle, Collected Studies on Francisco Suárez (1548-1617); Daniel Schwartz, ed., Interpreting Suárez: Critical Essays (Cambridge: Cambridge University Press, 2012); Hill and Lagerlund, eds., The Philosophy of Francisco Suárez; Sydney Penner, "The Pope and Prince of All the Metaphysians: Some Recent Works of Suárez," British Journal for the History of Philosophy 21 (2013): 2-16; Victor M. Salas and Robert L. Fastiggi, eds., A Companion to Francisco Suárez (Leiden: Brill, 2014); Gonçalo Pistacchini Moita, A modernidade filosófica de Francisco Suárez (Lisbon: Imprensa Nacional-Casa da Moneda, 2014).

8 A final contribution relevant to historical criticism of the "Black Legend" can be seen in John W. O'Malley, Saint or Devils Incarnate?: Studies in Jesuit History (Leiden: Brill, 2013). 
their historical fertility and separating the wheat from the chaff in this thinking and way of conceiving the world. The purpose is to understand the origins of our socio-cultural poverty and recover the best qualities of this tradition in terms of its possible contribution to present historical progress.

To this end, I seek to undertake a task of socio-historic reflexivity. In this regard, I need and seek to meet the historical challenges that face us. For this reason, the approach is not traditionalist or imitative but critical and reflexive, seeking to be honest about its novelty and historical difference. Hence, this paper is not about sanctifying but about seeking inspiration in a path such as the Ignatian and Jesuit tradition, which, with its own complexity and despite its own contradictions and errors, continues to issue its call, socially and institutionally, and, in the most valuable aspect of its work, strives to find answers that reconcile our world.

In this regard, I am equally aware of the historical nature in which every tradition plays out, in both the conveyance and appropriation of ways of social realization. Every appropriation or re-appropriation requires a task of adopting, transforming, and sometimes even abandoning elements specific to what is conveyed. This task is the responsibility of those who press on in the march of history. For this reason, the task is not about considering what is being transmitted as something closed, finished, and mechanically repeated over time and in different contexts. I believe the task is a reflexive reading of the possibilities offered, whether they are developed or not, based on a pluralist and changing social body. Therefore, this article is an exercise in appropriating some possibilities based on what is seen as the overcoming of other sociohistorically deficient paths. ${ }^{9}$

The ultimate and practical scope of the challenge would be to mobilize ways of life that produce human wealth and sustainability in the global context of plurality. Thus, the challenge is not simply about seeking truths, clarities, or an archaeological illustration of the past but about reconstructing our world from ways of life with human quality. These are ways of life that do not deplete human creativity and wealth and that recognize they are fragments ${ }^{10}$ of human nature and knowledge while not promoting fragmentation. In so

9 In this vein, my proposal for a critical hermeneutic reading of this tradition can be seen in Juan Antonio Senent-De Frutos, "Hacia una relectura de la matriz cultural ignaciana desde nuestras necesidades civilizatorias actuales," Concordia: Internationale Zeitschrift für Philosophie 66 (2014): 25-48.

10 José Casanova ("Interview," in La Vanguardia, May 31, 2018) recently re-examined this aspect from the perspective of sociology of culture and religion to advance a perspective I call intercultural: "No religion, no ethical theory, no philosophy has a monopoly on the answers; rather, we need all the accumulated knowledge of all these human traditions to live together and function as humanity." 
doing, they can collaborate and dialogue with other fragments, each making a specific contribution to common humanity, and seeking a personal, social, ecological, intercultural, and interfaith quality for a peaceful coexistence that sustains the world's plurality. In this regard, we need to recover traditions of wisdom that assume specificity and that uphold common recognition and care for what is human. In my view, an original and ongoing vocation exists also in the Ignatian and Jesuit tradition for this second aspect of caring for the common good.

This care can be understood historically in some experiences and in ongoing Jesuit and Ignatian efforts based on the agreements and guidelines defined in the decades following the Vatican Council through their general congregations. Through this focused, concerned, and discerning reading, I seek to recover the historical novelty and critical potential that appear prominently in some of its members and historical achievements. ${ }^{11} \mathrm{I}$ believe this interpretation is neither random nor arbitrary. For this reason, light must be shed on the source that gave rise to the cultural core of these achievements in various social fields, to then respond to the current challenges with greater awareness and efficacy.

I consider modernity, now in its dominant or hegemonic version, and judge it from my historical perspective, in both a cultural and a broader civilizational sense, as a developmental path for the whole of society, originating in Europe and the West, and intended to be a model to be appropriated by or imposed on the rest of the world's peoples. Many have spoken of and diagnosed a certain "crisis of modernity," mainly since the mid-twentieth century. This crisis does not imply a denial of its success or its historical strength in shaping the ways of life of different peoples, nor its benefits in terms of ethics, science, and material development. Instead, the crisis refers to a critical awareness of the limits of modernity's ability to fulfil its promises of human emancipation and an awareness that it is socio-economically unsustainable over time on the

11 In this regard, I highlight the latest contribution of Bartomeu Melià, S.J., "Las reducciones jesuíticas de guaranies en el marco teológico jurídico de la Escuela Ibérica de la Paz," Antíteses 21 (2018): 18-38, doi: 10.5433/1984-3356.2018v11n21p18. In this study, Melià shows how the Jesuit tradition projected in the "Iberian School of Peace," and especially through authors such as Suárez, can be seen as being in harmony with the achievements of the Guarani reductions. 
planetary level. ${ }^{12}$ This awareness involves both an "internal" difficulty and a fundamental shortcoming in its hegemonic or dominant version with regard to the outside world or towards other peoples as a mission that is rational and rationalizes the human and non-human worlds unilaterally and imposed in a complex and ensuing mission of ongoing colonization.

In this regard, I reflect a vision of the crisis of modernity from its exteriority or periphery, conducted within the heart of the Jesuit Latin American Philosophical Reflection Group (1983), where it was suggested that the hegemonic line produced by globalized modernity entails a breakdown of humanizing and founding relations of individuals, groups, and institutions with regard to others, nature, and God. The group's analysis denounces the view that casts man as no more than an economic being (consumer-producer) or a political one (a diminished and manipulated abstract citizen), that sees nature as only an economic resource, and that relegates God to a merely regulatory role. Thus, the "dominant cultural horizon, whose explanatory matrix is found in the Enlightenment, must be judged on its negative effects: a mass of surplus people, nature plundered and destroyed, God functionalized [...] and a general breakdown of humanizing and founding relationships."13

Thus, according to Juan Carlos Scannone, S.J., the historical meaning expressed in the Western modern mission with regard to other lands and peoples is the "will to absolutization"14 that marks the end of what is new in history, not leaving other peoples in their original state. Enrique Dussel shows that the egology of Cartesian knowledge of the ego cogito (I think) is historically and politically preceded by an imperial egology of the ego conquirus (I conquer). In this light, modern epistemology and anthropology are considered pre-existing elements in a political and imperial mission of European peoples toward the "new world."15

12 A biting analysis of the impossibility of practical universalization and the material or ecological unsustainability of modern capitalist civilization can be found in Ignacio Ellacuría, S.J., "Utopía y profetismo," in La lucha por la justicia (Bilbao: Universidad de Deusto, 2012), 401-49.

13 In my opinion, this collective text is headed by Ignacio Ellacuría, S.J. (1930-89) and appears in La lucha por la justicia: Selección de textos de Ignacio Ellacuría (1969-1989), Juan Antonio Senent, ed. (Bilbao: Universidad de Deusto, 2012). The Ellacuría Archive of the UCA of El Salvador, Central America, contains two manuscripts written by Ellacuría with his own sketches for this same document.

14 Juan Carlos Scannone, "Ontología del proceso auténticamente liberador," Panorama de la teología latinoamericana 1 (Salamanca: Sígueme, 1975), 246-87, here 256.

15 Enrique Dussel, El encubrimiento del otro: Hacia el origen del mito de la modernidad (La Paz: UMSA, Faculty of Humanities and Education Sciences; Plural Editors, 1994). 
In a similar vein, analyses by the authors of the de-colonial shift show that modernity is a way of projecting a particular form that spreads around the world through imperialism. That is the problem of modernity, so the modern deficiency is the will and successful ability to become universal in a despotic manner. The question then is the inherent inability to coexist with economic, political, legal, religious, gender, or racial differences. The resulting problem is that this inability impedes the lives of others, who will either be assimilated into the hierarchy or eliminated. Mignolo describes this shortfall as modern/ colonial racism. ${ }^{16}$

From this explanation, I gather some challenges to face and attempt to respond to in our era. First, in the field of social inclusion of others or cosmopolitan justice; second, in how the plurality of ways of life, conditions, and knowledge should properly be treated; third, in terms of how we treat the natural world in which we live, as it is our common home; and fourth, with regard to how the relationship with transcendence should be articulated.

Therefore, if the Ignatian tradition develops at the same historical time and geopolitical context, the relevant question for us is whether this tradition and its thinking respond to the same assumptions and fundamental values that hegemonic modernity itself has historically implemented. Conversely, I address whether this tradition that also arises during the development of modernity presents an alternative way of facing the challenges mentioned above. ${ }^{17}$ I consider this problem in the next section.

\section{$3 \quad$ Modernity and "Ignatian Modernity"}

If we consider the cultural developments that have occurred in Europe since the sixteenth century, a diversity of missions can be identified. In his review of the course and internal shifts in European modernity and its global spread, Stephen Toulmin notes that sixteenth-century humanism starts to be displaced in the seventeenth century, which he refers to as a "Renaissance" and a

16 Walter Mignolo, "Geopolítica de la sensibilidad y del conocimiento: Saberes, (de)colonialidad, pensamiento fronterizo y desobediencia epistémica," Revista de filosofía 74 (2013): $7^{-23}$.

17 One can find both a presentation of the limits of hegemonic modernity and a demonstration of the diversity of civilizational projects or "modernities" present in modern times, with consideration of the Ignatian and Jesuit tradition that I propose to interpret as a different modernity ("Ignatian Modernity" as I have termed it), in Juan Antonio Senent-De Frutos, "Ignatian Modernity as Another Kind of Modernity," Reformation(en) und Moderne: Philosophisch-Theologische Erkundungen (Vienna: Vienna University Press, 2017), 153-71. 
"Counter-Renaissance."18 This displacement involves a change in the cultural mentality that prioritizes a rationalist mission of modernity, oriented towards the quest for certainty, for security, for what is generalizable and atemporal. This process involves the cultivation of a rationalist philosophy and the development of the physical and mathematical sciences, making way for the European Enlightenments. Hence, according to Toulmin, the misunderstanding occurred largely in the early seventeenth century, a time when Descartes promoted a paradigm of knowledge that renounced "fields of study such as ethnography, history or poetry, so rich in content and context, to concentrate exclusively on abstract and decontextualized fields such as geometry, dynamics and epistemology."19

In this regard, authors such as Descartes establish in the field of European culture this new orientation as the most authentic or characteristic element of the modern spirit. Its counterpart is an epistemically abstracted, decontextualized, and disembodied subject. This subject is reduced to individual in the personal aspect and to a single "rational" model of being human and responding to what is real: to a single cultural pattern that supposedly has the legitimacy and ability to impose itself on all others and replace them. At the epistemic level, this subject even becomes absorbed by knowledge itself. As Xavier Zubiri suggested, Descartes is the thinker who realized this process in which "man is (not) a piece of the universe, something that is there [...]. Descartes severs the link that joins knowledge to what man is and turns knowledge into man's very being. ${ }^{20}$ In this context, the subject is no longer a piece of the universe, nor a rational creature, but something in whose knowledge the whole universe is contained. Therefore, the subject is no longer dust in the universe but envelops it.

Thus, in view of this modern path taken since the seventeenth century, Toulmin retraces the history of modernity to the sixteenth century, with the emergence of rhetoric as an intellectual strategy for adapting to the diversity of subjects, the context, the singular, and the temporal. This process sends the cultural field in a different direction. This cultural paradigm would therefore clash with the paradigm of objectivity inherent in the intellectual strategy of the seventeenth and subsequent centuries. However, this other intellectual strategy can be recognized in more than only the major intellectuals of the sixteenth century; as the work of John W. O'Malley shows, ${ }^{21}$ the Society of Jesus

18 Stephen Toulmin, Cosmópolis: El trasfondo de la Modernidad (Barcelona: Península, 2001), 51 .

19 Toulmin, Cosmópolis, 19.

20 Xavier Zubiri, Naturaleza: Historia y Dios (Madrid: Alianza Editorial, 1994), 285.

21 O'Malley shows that "one aspect of the forma mentis rhetoric was its mandate to adapt, an aspect that coincided with the Jesuits' way of working, which permeates everything." Los primeros jesuitas (Bilbao-Santander: Editorial Mensajero y Sal Terrae, 1993), 314. 
can also be viewed as a religious institution that is specifically "modern" in its attention to the particular, in its approach of adaptation or accommodation to what is personal and cultural. ${ }^{22}$ I believe this is a fair characterization of this tradition, as it is in harmony with those that appear in the Constitutions of the Society of Jesus about the Jesuit manner of government or the strategy of intervention, communication, and accommodation in practice and in each context of intervention. These statements describe a strategy that does not intend to be "remotely directed" but that intends to allow a "rhetorical adaptation" or accommodate people, times, and places to achieve a better match in interacting with other subjects and with reality. ${ }^{23}$ This interpretation is in keeping with the historical experiences and achievements of the Jesuits who sought to adapt to the subjects to whom the interventions were directed to prevent any situations that could generate or perpetuate despotism. Examples include the reductions of Paraguay, the Chinese Rites controversy, and the dialogue of knowledge and the interest and care for others' cultures, as can be recognized in Jesuit pioneers of "accommodation" and enculturation such as Alessandro Valignano (1539-1606), Matteo Ricci (1552-1610), and Michele Ruggieri24 $\left(1543^{-1607)}\right.$ in Asia or Alonso de Barzana (1530-97) in the Americas. ${ }^{25}$ These forms, which were adaptive and respectful of social interaction, were later combated in the seventeenth and eighteenth centuries by a spirit of uniformization and colonization. Therefore, in view of the modern colonial geopolitics that the European powers have been projecting around the world with more clarity and intensity since the seventeenth century, Ignatian modernity has generally articulated a geopolitics of coexistence ${ }^{26}$ with care for the peoples of the world and their cultures. In my view, this difference was not respected by

22 Stephen Schloesser, "Accommodation as a Rhetorical Principle: Twenty Years after John O'Malley's The First Jesuits (1993)," Journal of Jesuit Studies 1, no. 3 (2014): 347-72, here 350, doi: 10.1163/22141332-00103001.

23 Constituciones de la Compañía de Jesús, ed. Santiago Arzubialde et al. (Bilbao-Santander: Mensajero-Sal Terrae, 1993), 91.

24 I point out here, while less well-known but equally important to defining the presence and dialogue of local and traditional culture in China, the pioneering work of the Neapolitan Jesuit (1543-1607) La filosofía moral de Confucio by Michele Ruggieri, who opened the door in China for Ricci and other colleagues. Also, the first translation of the works of Confucius to Spanish by Thierry Meynard, S.J. and Roberto Villasante, S.J., eds. (Bilbao-Santander: Mensajero; Sal Terrae; Universidad Pontificia de Comillas, 2018).

25 Wenceslao Soto, S.J., Alonso de Barzana, SJ (1530-1597): El Javier de las Indias Occidentales (Bilbao: Mensajero, 2018).

26 See Thomas Banchoff and José Casanova, eds., The Jesuits and Globalisation: Historical Legacies and Contemporary Challenges (Washington, DC: Georgetown University Press, 2016). 
the European powers, which fought to suppress the Society of Jesus, first politically and then ecclesiastically. ${ }^{27}$

In a similar vein is Karl Rahner's (1904-84) analysis of the modern character of the Jesuit institution and the spirituality that underlies and upholds it. Rahner, referring to Ignatius Loyola in the first person, notes that "what strikes me as new and peculiar is typical of this Modern Age."28 In this regard, he highlights the defense of individual freedom of conscience through moral probabilistic theology. He also describes a defense of a humanism that seeks to safeguard freedom and human nature and that is open to the proposal of humanizing and saving the other cultures of mankind. ${ }^{29}$ This rich and optimistic view of the possibilities of human beings is also based on "mystical or religious individualism." A person can have an internal and personal experience of God. Even a person's integration into a community or ecclesial mediation does not nullify or replace the centrality of this possibility. Therefore, ecclesial obedience, in this context, cannot consist of the inauthentic and heteronomous fulfilment of religious or ecclesial mandates. ${ }^{30}$

In the last century, many authors have debated the role and relationship of Suárez to modern times and their development. The intense debate that has taken place ${ }^{31}$ shows the problematic character that modernity assumes with regard to Suárez and the consequent difficulty of accepting the dominant historical version that holds René Descartes (1596-1650) to be the father of modern philosophy. Although Suárez's influence on the development of modern thinking as well as legal and political institutions has been described at length by many researchers, debate remains over whether his work can be characterized as modern. Even if the modernity of his thinking is recognized, one must ask whether this thinking has a different character and is based on other assumptions, ${ }^{32}$ or if he simply shares platitudes with modern thinkers.

27 Jean Lacouture, Jesuitas I (Barcelona: Paidós, 2006), 531-79.

28 Karl Rahner, Palabras de Ignacio de Loyola a un jesuita de hoy (Santander: Sal Terrae, 1979), 32.

29 Rahner, Palabras de Ignacio de Loyola a un jesuita de hoy, 26.

30 Rahner, Palabras de Ignacio de Loyola a un jesuita de hoy, 5-6.

31 Part of the same is published in Robert C. Minner, "Suárez as a Founder of Modernity: Reflections on a topos in Recent Historiography," History of Philosophy Quarterly 18, no. 1 (2001): $17-36$.

32 I share the question Gonçalo Moita Pistacchini raises about the modern character of Suárez's work and about the distinctive character of his work compared, for example, with Cartesian modernity in his A modernidade filosófica de Francisco Suárez, 267-82. 
Therefore, we must ask ourselves what is the most appropriate way of interpreting Suárez's thought. ${ }^{33} \mathrm{~A}$ frequent response to the question of his modernity situates Suárez's work as a transition between the medieval and modern philosophies. Along these lines, Benjamin Hill places Suárez between medieval, Renaissance, and early modern philosophies. ${ }^{34}$ Specifically, and with a decisive impact on subsequent interpretations of Suárez over the twentieth century, Martin Heidegger (1889-1976) situated the Jesuit philosopher's thinking as a bridge between medieval and modern philosophy. Thus, in his work Being and Time (1927), Heidegger pointed to Suárez as the author who brings Greek ontology to modern philosophy ${ }^{35}$ and whose impact ranges from Descartes to Hegel (1770-1831). Zubiri also highlights how, especially in his Metaphysical Disputations, Suárez develops "material" or medieval philosophical concepts that will show up in the development of European philosophy in the seventeenth century. ${ }^{36}$ Zubiri makes public Heidegger's comment that "Suárez is the hinge around which medieval philosophy takes its decisive turn towards modernity. 'Der ist der Mann' (He is the man), he used to say." ${ }^{37}$

33 Another interpretative difficulty presented by Suárez arises from what several authors describe as "eclecticism." Thus, for some, his work has a heterogeneous character, a hybrid of various, even contradictory, theoretical and doctrinal positions. I believe the question is about the inspiring and unifying criterion of his work. Suárez's dialectic capacity-which takes the form of being able to consider doctrinal contributions of different schools throughout the history of thought and scrutinize their possible contribution to the examination of the question at hand-is not eclecticism, nor absence of his own perspective. In this regard, Marco Forlivesi has linked this form of Suárez's intellectual process to a requirement in Ratio studiorum, approved in 1599, that when treating a diversity of opinions, the professor must seek "to reconcile the different positions." See "Francisco Suárez and the rationes studiorum of the Society of Jesus," in Francisco Suárez and His Legacy: The Impact of Suárezian Metaphysics and Epistemology on Modern Philosophy, ed. Marco Sgarbi (Milan: Vita e pensiero, 2010), 77-90, here 81. I also note that this position is in line with the basic attitude that takes the known as the "presupposition" (Ex. 22), which Loyola proposes in the Spiritual Exercises for any Christian with regard to any process of dialogue or treatment of the other.

34 See footnote 5 .

35 Martin Heidegger, Ser y tiempo, trad. J. E. Rivera (Santiago de Chile: Editorial Universitaria, 2008), 46.

36 Xavier Zubiri, Francisco Suárez: Disputaciones metafisicas sobre el concepto del ente; Traducción del latín, introducción, advertencia preliminar (Madrid, Editorial Revista de Occidente, 1935), 7-10. In this regard, Sergio Rábade Romero, among others, notes the philosophical impact of Suarezian metaphysics on German, French, Dutch, and English philosophy in Suárez (1548-1617) (Madrid: Ediciones del Orto, 1997), 52-58.

37 Xavier Zubiri, "Presentación del tratado De anima de F. Suárez," Escritos menores (Madrid: Sociedad de Estudios y Publicaciones, 2006), 288. 
Thus, from this position as a transition or "hinge" helping to develop modern philosophy, Suárez can be understood as an "influence" that can be recognized in the work of typically modern philosophers such as Descartes, Baruch Spinoza (1632-77), or Gottfried W. Leibniz (1646-1716), among others. Suárez's work played this role for various modern thinkers. However, I do not share this perspective, which ultimately portrays his work as merely "extemporary" or outside his own time. This line of interpretation follows in the wake of Hegel, whose Nineteenth-Century Lectures on the History of Philosophy presented Descartes as the initiator of modern philosophy. This vision excludes the Jesuit authors from the second Scholasticism ${ }^{38}$ or baroque Scholasticism, headed by Suárez of philosophical modernity. While the Society of Jesus is often recognized as a modern religious order due to its birth, character, and development, this same character does not appear to be applied to its thinkers. On the other hand, I cannot interpret its modernity according to its influence on indisputably modern authors ${ }^{39}$ such as Descartes or John Locke (1632-1704), as if these composed the canon of modernity. In this case, Suárez's alleged modernity would consist of material reused by others, who have taken some of his theoretical elements and placed them in other systems of thought to serve other achievements or social institutions. On the contrary, I understand that we need to read Suárez as an author who, without holding a monopoly on modernity, develops a different path for it.

Therefore, although Suárez did not propose solutions similar to those of other typically modern authors, he nevertheless developed his work from the same community of problems faced by them. I believe his work does not develop extrinsically to modern culture. I share José Ferrater Mora's observation about Suárez and the Jesuit philosophers that they are "to a certain extent modern philosophers, not only because they are influenced by modern or pre-modern philosophers, but because they attempted to answer the same problems posed by philosophers considered modern in the strict sense." 40 The time period is not extrinsic to the works of philosophers. ${ }^{41}$ Specifically, Suárez and the other Jesuit philosophers of the second Scholasticism, who shared a historical period with modern philosophers, sought answers to the same problems. In fact, they directly and indirectly influenced them, and as Ferrater Mora

38 Carlo Giacon, La seconda scolastica: Precedenze teoretiche ai problemi giuridici; Toledo, Pereira, Fonseca, Suárez (Turin: Nino Aragno editore, 2001), 193-365.

39 Giovanni Cucci, S.J., "Francisco Suárez: Il padre della modernità filosófica," La Civiltà cattolica IV (2017): 441-43.

40 "Suárez y la filosofía moderna," in Cuestiones disputadas: Ensayos de filosofía (Madrid: Editorial Revista de Occidente, 1955), 151-77, here 156. Ferrater Mora, Cuestiones disputadas, 152. 
notes, the influence of Spanish Scholasticism on modern philosophers occurred because it belonged "in some essential aspects to the modern spirit." One feature of this modernity is the development of an epistemologically autonomous metaphysics. In this regard, Suárez's specific contribution was to lay the foundations for the ontological principle from which human existence derives. However, this common commitment to developing an autonomous philosophy, rather than merely an ancilla theologiae (servant of theology), is carried out by the movement known as baroque Scholasticism based on assumptions that differ from those underlying other modern developments. For example, its humanism does not appear to be self-sufficient and free-floating but seems to be founded in and open to transcendence. Neither does it take an individualistic perspective; rather, without denying personal dignity and individual freedom, it understands a person's nature as also inherently social and normatively situated on a horizon of the common good, ${ }^{43}$ which is the measure of the correct fulfilment of the individual and their own rights.

Suárez's work helps develop the path of the civilizational reconstruction of the medieval order in crisis and renewal in the sixteenth century. It also represents one response to the medieval world and a different response to the main direction that political modernity takes. My view is that its answers reveal the key to an "Ignatian Modernity."44 Modernity is not a monologic cultural process; rather, various traditions have flowed together and developed in Europe since the sixteenth century. In this plurality of responses to the challenges of the modern era, I believe that the specificity and difference of thought elaborated by the Jesuit authors, and by Suárez in particular, deserve recognition. This current of modernity, which I can term "Jesuit" or "Ignatian," has a spiritual foundation that until now has been considered merely an inspiration for Jesuit philosophical thought.

Suárez is recognized as a Jesuit philosopher because he belonged to this religious order from 1564 to his death in 1617 . However, this descriptor does not merely define the biographical framework in which he lived his life in an external and circumstantial sense; rather, I can recognize it as the source of inspiration for his philosophical, theological, or legal work. I see this same fundamental intuition in the treatment that Pope Paul V(r.1605-21) granted Suárez, ${ }^{45}$ recognizing him as Doctor eximius ac pius. His intellectual excellence cannot

42 Ferrater Mora, Cuestiones disputadas, 157.

43 Ignacio Sepúlveda del Río, "El bien común en los inicios de la Compañía de Jesús: Desde los primeros años hasta el pensamiento de Francisco Suárez," Pensamiento 74, no. 279 (2018): 163-78, doi: 10.14422/pen.v74.i279.y2018.008.

44 See footnotes 9 and 17.

45 The title comes from the breve of October 2, 1607. 
be separated from his deep spirituality. In this same vein, the inspirational core or the source of Jesuit charisma and that of their Christian religious order is found in the Spiritual Exercises of Ignatius. ${ }^{46}$ However, this Jesuit thinker also had a prominent role in the education and thought of the Society of Jesus. ${ }^{47}$ Both the Spiritual Exercises ${ }^{48}$ and the Jesuit order are a mid-sixteenth-century response to the challenges posed at that time to the Jesuits and the church by early modernity in Europe and the rest of the world. These Exercises propose a method of prayer that does not consist merely of a form of indoctrination but is a method of working ${ }^{49}$ with sensitivity and affectivity (which are at the foundation of the soul's powers), which involves a "libidinal reconversion."50 This proposal enables the subject ${ }^{51}$ to use creativity to develop other ways of responding to reality and, in this case, face other responses from his Christian perspective. This option permits a clearer understanding of the background of the meaning of Suárez's metaphysical conception. The understanding is metaphysical, in which reality and human beings are permeated by the divine presence that desires and works for the good of his subjects and creation. ${ }^{52}$ Therefore, in the world view that arises from the Exercises, creatures (that Suárez

46 Benedict XVI, Discurso de su Santidad Benedicto XVI a los participantes en la $35^{a}$ Congregación General de la Compañía de Jesús, https://w2.vatican.va/content/benedict-xvi/ es/speeches/2008/february/documents/hf_ben-xvi_spe_20080221_gesuiti.html, 2008 (accessed December 23, 2018).

47 Félix Rodríguez, S.J., "Suarismo," Diccionario histórico de la Compañía de Jesús, ed. Charles O’Neill, S.J. and Joaquín Ma Domínguez, S.J. (Madrid-Rome: Institutum Historicum S.J.; Universidad Pontificia de Comillas, 2001), 3654-56, here 3654 .

48 See Ignatius of Loyola, Exercitia Spiritualia: Textuum antiquissimorum nova editio; Lexicon textus Hispani, Monumenta Historica Societatis Iesu 100 (Rome: Institutum Historicum Societatis Iesu, 1969).

49 Aranguren observed more than half a century ago that Ignatian tradition is not merely a form of spirituality, nor is it a religious matter, but that as it works with the structures of human subjectivity, it generates an ethos that has a social and historical virtuality. This author called it the "Ignatian school of character building." José Luis López Aranguren, Ética (Madrid: Biblioteca Nueva, 2003), 71.

50 Carlos Domínguez, Psicodinámica de los Ejercicios espirituales (Santander: Editorial Sal Terrae-Mensajero, 2003), 43.

$5^{1}$ The core of Ignatian uniqueness lies in its work with the inner life of the subject to enable another freer and more humanizing practice. However, this moral capacity is also recognized and seeks to empower others. It is about considering them subjects who are capable (or who can be helped to be more capable) of achieving a proper praxis. It is not simple heteronomous indoctrination or mere imposition but above all the recognition of a common humanity, of one's autonomy, from which also follows the ability to criticize what is considered deviant (Ex. 22). As a result, the Jesuits could practice what we would call today an intercultural and inter-religious dialogue. 
understood to be "finite beings") find themselves in a basic, provident, and guiding relationality with the greatest good. The latter, by its likeness to God, bestows on the human condition a responsibility to itself and to all of creation to work together towards this good. When it operates in the political field, this responsibility should be guided by a search for what Ignatius termed the most universal good or, in classical terms, by the criterion of the common good.

Jesuit historian Stephen Schloesser ${ }^{53}$ also points to the modern character of Suárez, separating it into five aspects and moving between polarities that cannot be dissociated and from which one must seek some sort of synthesis of opposites. The first aspect of Suárez is that he ambiguously encompasses both the sixteenth-century Renaissance, an era of skepticism derived from nominalism, and the seventeenth-century baroque, characterized by what Toulmin terms a "Counter-Renaissance" in search of certainty. Second, human knowledge of God's radical alterity would be impossible without differences in being and without analog thinking, yet without the uniqueness of being, science would be impossible and metaphysics itself could not be a science-all this at a time of "scientific revolution." Third, the recognition of the principle of individuation, according to which everything individuates itself, does not require any other principle of individuation. Fourth, extending this principle to epistemology, human beings can have "direct knowledge" of unique existing materials, not merely universal abstracts. This interpretation is in opposition to Thomas Aquinas (1224/5-74), for whom the intellect cannot grasp knowledge of individuals; as these are material, they cannot be directly known by the intellect (which is immaterial). Fifth, Suárez was welcomed by reformed Scholastic philosophers during the bloodbath that pitted Protestants against Catholics in the Thirty Years' War (1618-48), which began the year after his death. Ironically, the Iberian Jesuit became a leading intellectual parent of the German Reformation, and his thought during the Counter-Reformation produced a legacy found in the works of Locke and Kant, among others.

For my part, I believe that the modern and Ignatian aspects of Suárez's character must be understood in an integrated manner, and in this regard, his interventions and attempts at synthesis must be understood as nurtured and enhanced by his Jesuit spirituality and manner of proceeding. The Jesuit tradition can be seen as a system of possibilities that emerged in sixteenth-century Europe as a way of responding to the European challenges of that time and to the new geographical, social, cultural, and religious contexts that opened with global access to the world. This Ignatian tradition is enhanced by Renaissance

53 Stephen Schloesser, "Review of Suárez's Metaphysics in Its Historical and Systematic Context, ed. Lukáš Novak," Journal of Jesuit Studies 3, no. 1 (2016): 85-92, here 85-86, doi: $10.1163 / 22141332-00301005$. 
humanism and Christian spirituality, which, as in Suárez's case, encouraged a path of Christian humanism ${ }^{54}$ already undertaken by the early generations of the Salamanca School, where he was an original participant, and which spread and even gave rise to what is now known as the Iberian School of Peace. ${ }^{55}$ At this school, the Jesuits, and especially Suárez, ${ }^{56}$ made important contributions to the interactions among the main Iberian universities. I can describe the core of his world vision as being "action that yields results." Eleuterio Elorduy ${ }^{57}$ uses this description when showing the relevance and pertinence of this metaphysical, gnoseological, and practical dimension in the Suarezian system. Thus, the type of actions that fall within the realm of resultantia applies neither to the internal working of the Trinity nor to purely transitive actions. In this regard, the world "is created" and man "is created." This creation includes transitive aspects but is not limited to them. Thus, the realm of results is the realm of "creation," including natural evolution, and integrates it into the complexity of the social, which is natural evolution, but in its optional creation it makes the historical possible as forms of reality liberated by societies. From this perspective, I believe one can understand that Ignatian spirituality, though not affirmed explicitly in each intellectual realm, is the core inspiration in Suárez's thought and for the Jesuit thinkers. This view allows a deeper understanding of the background of the meaning of Suárez's metaphysical conception. It holds that all reality, including human beings, is permeated by the divine presence that desires and works for the good of his subjects and creation. From the perspective that emerges from the Spiritual Exercises, creatures find themselves in a fundamental, provident, and guiding relationality with the highest good. This fundamental relationality means that human beings must be engaged in cooperatively searching for and carrying out good. Thus, human activity is the locus of God's action. Therefore, this concept refers to an anthropology open to transcendence whose action can

54 This concept is situated in the line of Christian humanism developed by the Society of Jesus. In this regard, see Peter-Hans Kolvenbach, "La pedagogía ignaciana: Un planteamiento práctico," in Kolvenbach, Discursos universitarios (Madrid: UNIJES, 2008), 126-39, here 126; John W. O'Malley, "Renaissance Humanism and the Religious Culture of the First Jesuits," The Heythrop Journal 31 (1990): 471-87.

55 Pedro Calafate, "A Escola Ibérica da Paz nas universidades de Coimbra e Évora (séculos XVI e XVII)," Revista de hispanismo filosófico 19 (2014): 119-42; Pedro Calafate, Mandado Gutiérrez, and Emilio Ramón, eds., Escuela Ibérica de la Paz: La conciencia crítica de la conquista y la colonización de América (Santander: Universidad de Cantabria, 2014).

$5^{6}$ Eduardo Ibáñez Ruiz del Portal, "Francisco Suárez y los derechos humanos: Corrientes historiográficas y perspectivas críticas actuales," Pensamiento 74, no. 279 (2018): 221-35, doi: 10.14422/pen.v74.i279.y2018.o11.

57 Eleuterio Elorduy, "La acción de resultancia en Suárez," Anales de La Cátedra Francisco Suárez 3 (1963): 45-76, here $5^{6 .}$ 
be conducted through historical implementation. It is a Christian humanism forming the background against which political, legal, and moral practice are interpreted. The concept is not purely theocentric, as the sacred acts through human beings. In the political sphere, this good is guided by the search for the most universal good, classically described as the common good. ${ }^{58}$ Suárez's metaphysical perspective causes him to shift the focus slightly away from access to the entity. The entity is seen in the light both of its maximum transcendental abstraction and in that of its giving of itself: its existential becoming. At various places in his work, such as in Defensio fide $i^{59}$ or in De legibus, ${ }^{60}$ Suárez treats the multiplicity and diversity of political forms not as a given, random, or extrinsic condition of social life but as the product of human activity that results in the diversity of political and legal forms. This interpretation opens the way to understanding political realities as historically constituted rather than external factors. This concept could consist of their dependence on social action rather than merely the successive course of political forms imposed on human action. This is the historical root of political forms. This concept means the historical process might even be understood not as something external to human life, deriving from an outside social existence, but in terms of its productive dynamism in social life. This dynamism owes its establishment, complexity, codetermination, and openness to human practice. History is not merely a social destiny guided by forces beyond human action but is deeply rooted in human production, a work of human authorship, even when Suárez does not see this authorship as ontologically separate or isolated from its ultimate and original foundation in God. However, this area of autonomy, responsibility, and creativity does not preclude human freedom; instead, it charges it with discovering and forging its historical path in search of the common good. Another relevant aspect is the relative autonomy of political order with regard to the people. Once instituted, the institutions of political modernity, the state and the law, are not autonomous or untethered bodies but are subject to the common good of the people. Thus, the transcendent operates politically through the people first, so public-state power and legal authority are not enshrined. Thus, civil or human law, even when autonomous, does not define itself in a normative vacuum, but its correction requires the exercise of right reason. Therefore, rationality is not absorbed or monopolized by the established power and remains a social or communal perspective capable of judging positivized normativity.

In this context and to note other features of the difference in Suárez's modernity, I can draw certain ethical assumptions from his practical philosophy

$5^{8} \quad$ De legibus (Madrid: cSIC, 1975), lib. III, c 3, n 8, 35.

59 Defensio fidei (Madrid: Instituto de Estudios Políticos, 1969), lib. III, c 2, n 18, 223.

6o De legibus, lib. III, c 3, n 8, 33-35. 
that are driving the treatment of legal and political issues. I recognize in his thought some elements that are liberating or respectful of human dignity and of others in a legal, moral, political, and religious sense. Moreover, I believe this ethical potential may result in his own Christian worldview. His approach reveals a consistent underlying ethical position. I identify the following elements. First, human life is treated as an axiological root or source. So-called "voluntary slavery" does not legitimize a merely factual or strategic treatment of subjects by the established power. Therefore, he does not admit processes of depersonalization ${ }^{61}$ or "degeneration" of human beings, nor of anyone who exercises power in a tyrannical manner as a "public enemy." 62 Hence, the reservations and precautions he requires to legitimize the serious case of removing a tyrant as self-defense. Second, and closely tied to the previous element, is the minimization of the historical production of deaths. This is a guiding criterion of practical reason that puts into practice care for human life. ${ }^{63}$ Third, given humans' social natures and the necessary practice of politics, care is given to the structural conditions of the common good. Therefore, political institutions must be respected and preserved as far as possible, for they are necessary and central to human life in society. Fourth, care must be shown for a discursive and ethically binding rationality that requires respect for procedures and observance of the normative requirements present in the same human dialogue, recognized in the principle of pacta sunt servanda. Fifth, I must refuse to enshrine figures of public authority. Respect, obedience, and recognition of the necessity of political power do not, in Suárez's view, extend to theological absolutism; thus, even while playing various roles, he maintained the fundamental equality of human beings, regardless of whether or not they were Christians. ${ }^{64}$

61 Luis Carlos Amezúa, "La cláusula suareciana sobre la esclavitud," Pensamiento 74, no. 179 (2018): 237-61, here 261, doi: 10.14422/pen.v74.i279.y2018.012.

62 Along with the treatment of this question in his work Defensio fidei, he proposes a spiritual treatment for relations with the enemy in Tractatus de oratione, devotione et horis canonici (Paris: Ed. L. Vives, 1859), lib. I, c 19, n 21, 73-74.

63 This concept can be seen in various situations, in addition to the well-known case of tyrannicide; see Pablo Font Oporto, El derecho de resistencia civil en Francisco Suárez: Virtualidades actuales (Granada: Ed. Comares, 2018). Other cases addressed by Suárez reveal this criterion that protects human life and its conditions of existence. Luis C. Amezúa, "Derecho de evasión y principio de humanidad: Notas de Francisco Suárez sobre la obligación penal y la fuga de presos," Anuario de filosofía del derecho 31 (2015): 103-36.

64 Even in the case of the Christian princes, Suárez did not consider their Christianity alone proof of political and moral superiority over pagan princes: "Power, as today is seen in the Christian rulers, is neither greater nor of a different nature than it was in the pagan rulers. On its own, it has no other purpose or object," De legibus, lib. III, c XI, n 9. 